\title{
Synthesis and Biological Activity Study of New Some Schiff Bases Derived From D-Erythroascorbic Acid
}

\author{
Rasmia M. Rumez*, Alia'a S. Abdul-Razaq ${ }^{* *}$, Dheefaf F. Hassan* and Zinah H. Hussin* \\ *Department of Chemistry, College of Education for Pure Sciences - Ibn-Al-Haitham, \\ Baghdad University, Baghdad-Iraq. \\ ${ }^{* *}$ Center for Market Research \& Consumer Protection, Baghdad University, Baghdad-Iraq.
}

\begin{abstract}
New Schiff bases derived from D-erythroascorbic acid were prepared by condensing pentulosono- $\gamma$-lactone-2,3-enedianisoate (V) with 3-amino phenol, (4-iodo, 3-methoxy, 4-methyl, 4-nitro) aniline in the presence of glacial acetic acid and dry benzene. The products were characterized by spectral methods FTIR, and some by (UV-Vis), ${ }^{1} \mathrm{H}$ and ${ }^{13} \mathrm{CNMR}$, mass spectra and measurement of its physical properties and evaluation of the biological activity for them.
\end{abstract}

Keywords: Schiff bases, imine, biological activity, erythroascorbic acid.

\section{Introduction}

The formation of carbon-nitrogen double bond plays important role in organic synthesis. This can be achieved by the reaction of aldehydes and amines in acidic medium which leads to synthesis of Schiff bases (imines). Schiff bases have attracted considerable attention of organic chemists due to their significant biological activities like anticancer [1], antitumor [2], anti-inflammatory agents [3], insecticidal [4], antibacterial [5], antituberculosis [6], antimicrobial [7], anticonvulsant [8] activity. The Schiff bases are also used as versatile components in nucleophilic addition with organometallic reagents [9] and in cycloaddition reactions $[10,11]$. The reaction of primary aromatic amines with aryl aldehydes is found to be catalyzed by lemon juice as natural acid under solvent-free conditions to give the corresponding Schiff bases in good yields. This eco-friendly reaction has many advantages like economical, environmental, mild reaction conditions and simple work-up with high product yield [12].

\section{Experimental}

Melting points were determined by electrothermal Stuart melting point apparatus and are uncorrected. IR spectra (in $\mathrm{KBr}$ ) were recorded on 8400s Shimadzu FT infrared spectrophotometer. ${ }^{1}$ HNMR spectra were recorded on Ultra Shield $(300 \mathrm{MHz})$ spectrometer with tetramethyl silane as internal standard. ${ }^{13} \mathrm{CNMR}$ spectrum was recoded on a Varian Mercury plus $100 \mathrm{MHz}$ spectrometer. Electronic spectrum was obtained using a (U.V-Vis) spectrophotometer type CECl 7200 England. Mass spectrum for the compound (V) was recorded on IEOLJMS7high resolution instrument. Thin layer chromatography (TLC) was performed on aluminum plates coated with layer of silica gel, supplied by Merck. The spots were detected by iodine vapor. All chemical were obtained from Fluka or BDH.

\section{Synthesis of 5,6- $O$-isopropylidene-L- ascorbic acid (II)}

Dry hydrogen chloride was rapidly bubbled with stirring for 20 minutes into a $(250 \mathrm{ml})$ flask containing $(10 \mathrm{~g}, 57 \mathrm{mmol})$ of powdered L-ascorbic acid (I) and (100ml) of dry acetone.

After addition of $(80 \mathrm{ml}) n$-hexane, stirring and cooling in an ice-water, the supernatant was decanted. The precipitate was washed four times with $(154 \mathrm{ml})$ of acetone-hexane mixture $(4: 7)$

$(\mathrm{v} / \mathrm{v})$, cooling in an ice-water and removal of supernatant after each addition. The last precipitate was dried under reduced pressure to give (II) (95\%) as a white crystalline residue [13], m.p (206-208 $\left.{ }^{\circ} \mathrm{C}\right) . \mathrm{R}_{\mathrm{f}}(0.68)$ (benzene: methanol, 5:5) (v/v). FTIR $\left(\mathrm{KBr}, \mathrm{cm}^{-1}\right): 3240$ (O-H), 2993 (C-Hali. $), 2908$ (C-Hace.), 1751 $\left(\mathrm{C}=\mathrm{O}_{\text {lac. }}\right), 1662(\mathrm{C}=\mathrm{C}), 1431$ (-CH-asym $), 1388$ $\left(-\mathrm{CH}\right.$-sym $_{\text {sy }}, \quad 1141-900 \quad(\mathrm{C}-\mathrm{O}), \quad 767 \quad \delta(\mathrm{O}-\mathrm{H})$ (O.O.P.) [14]. 
Synthesis of 2,3-O-dianisoyl-5,6-O-

isopropylidene - L-ascorbic acid (III)

To a cold solution of (II) $(10 \mathrm{~g}, 46 \mathrm{mmol})$ in pyridine $(50 \mathrm{ml})$, anisoyl chloride was added as dropwise $(17.5 \mathrm{ml}, 129 \mathrm{mmol})$ with stirring. The resulting mixture was stirred for 2 hours, then kept in dark place at room temperature for 22 hours.

The mixture was poured into ice-water and stirred for 20 minutes, the supernatant was decanted. The oil layer was extracted with chloroform $(150 \mathrm{ml})$, washed with water, dilute hydrochloric acid (5\%) (2×100ml.), saturated aqueous sodium hydrogen carbonate $(100 \mathrm{ml})$ and water. Dried over anhydrous magnesium sulfate. Chloroform was evaporated to produce a brown syrup and purified from chloroform: petroleum ether (60$\left.80^{\circ} \mathrm{C}\right)(1: 5)(\mathrm{v} / \mathrm{v})$ to give (III) $(76.5 \%)$ as a pale yellow solid[15], m.p $\left(102-104^{\circ} \mathrm{C}\right) . \mathrm{R}_{\mathrm{f}}(0.80)$ (benzene: methanol, 5:5) (v/v). FTIR (KBr, $\left.\mathrm{cm}^{-1}\right)$ : 3028 (C-Har. $), 2983$ (C-Hali. $), 2939$ $\left(\mathrm{C}-\mathrm{H}_{\text {ace. }}\right), 2843 \quad\left(\mathrm{OC}-\mathrm{H}_{\text {ali. }}\right), 1749 \quad\left(\mathrm{C}=\mathrm{O}_{\text {lac. }}\right)$, $1683\left(\mathrm{C}=\mathrm{O}_{\text {est. }}\right), 1647\left(\mathrm{C}=\mathrm{C}_{\mathrm{ali}}\right), 1604\left(\mathrm{C}=\mathrm{C}_{\mathrm{ar}}\right)$, 1300-1107 (C-Oest.), 900-600 $\delta(\mathrm{C}-\mathrm{H})$ (O.O.P.) [14].

\section{Synthesis of 2,3-O-dianisoyl-L-ascorbic acid (IV)}

Compound (III) $(10 \mathrm{~g}, 23.6 \mathrm{mmol})$ was dissolved in mixture (65\%) acetic acid (30ml) and absolute methanol $(10 \mathrm{ml})$ and stirred for 48 hours at room temperature. The TLC showed that the reaction was complete (benzene: methanol, 6:4).

To the resulting solution a benzene $(40 \mathrm{ml})$ was added and evaporated (repeat this process four times)[15].The residue recrystallized from chloroform and then diethyl ether to yield (IV) $(77.7 \%)$ as a white crystals, m.p $\left(130-132^{\circ} \mathrm{C}\right)$, $\mathrm{R}_{\mathrm{f}}(0.42)$. FTIR $\left(\mathrm{KBr}, \mathrm{cm}^{-1}\right): 3444(\mathrm{O}-\mathrm{H}), 3008$ (C-H ar. $), 2972\left(\mathrm{C}-\mathrm{H}_{\text {ali. }}\right), 2843\left(\mathrm{OC}-\mathrm{H}_{\text {ali }}\right), 1741$ $\left(\mathrm{C}=\mathrm{O}_{\text {lac. }}\right), 1681\left(\mathrm{C}=\mathrm{O}_{\text {est. }}\right), 1647\left(\mathrm{C}=\mathrm{C}_{\text {ali }}\right), 1606$ $\left(\mathrm{C}=\mathrm{C}_{\text {ar. }}\right), \quad 1319-1112 \quad\left(\mathrm{C}-\mathrm{O}_{\text {est. }}\right), \quad 900-600$ $\delta\left(\mathrm{C}-\mathrm{H}_{\mathrm{ar}}\right)($ O.O.P.) [14].

\section{Synthesis of pentulosono- $\gamma$-lactone-2,3- enedianisoate (V)}

To the stirred solution of sodium periodate $(5.6 \mathrm{~g}, 26 \mathrm{mmol})$ in distilled waer $(60 \mathrm{ml})$ at $\left(0^{\circ} \mathrm{C}\right)$, a solution of (IV) $(10 \mathrm{~g}, \mathrm{t} 26 \mathrm{mmol})$ in chloroform $(60 \mathrm{ml})$ was added dropwise. After stirring for 15 minutes, ethylene glycol $(0.5 \mathrm{ml})$ was added as dropwise, stirring was continued at room temperature for 1 hour [15].

The mixture was filtered and to the filtrate water $(40 \mathrm{ml})$ was added then the product was extracted with ethyl acetate $(3 \times 50 \mathrm{ml})$, the extracts dried by anhydrous magnesium sulfate, then filtered and the solvent was evaporated and the residue recrystallized from benzene to yield the pure product of compound (V) (45\%) as a white crystals, m.p $\left(156-158^{\circ} \mathrm{C}\right) . \mathrm{R}_{\mathrm{f}}(0.70)$ (benzene: methanol, 6:4) (v/v). FTIR $\left(\mathrm{KBr}, \mathrm{cm}^{-1}\right): 3040\left(\mathrm{C}-\mathrm{H}_{\mathrm{ar}}\right)$, $2983\left(\mathrm{C}-\mathrm{H}_{\text {ali. }}\right), 2843\left(\mathrm{OC}-\mathrm{H}_{\text {ali. }}\right), 2671,2559$ (C-H $\left.\mathrm{H}_{\text {ald. }}\right), 1782\left(\mathrm{C}=\mathrm{O}_{\text {lac. }}\right), 1749\left(\mathrm{C}=\mathrm{O}_{\text {ald. }}\right), 1685$ $\left(\mathrm{C}=\mathrm{O}_{\text {est. }}\right), 1604\left(\mathrm{C}=\mathrm{C}_{\text {ar. }}\right), 1300-1107\left(\mathrm{C}-\mathrm{O}_{\text {est. }}\right)$, 900-600 $\delta\left(\mathrm{C}-\mathrm{H}_{\text {ar. }}\right)\left(\right.$ O.O.P.). ${ }^{1} \mathrm{HNMR}$ (DMSO $\delta$ ppm): 12.5 (s, 1H, CHO.), 7.00-7.96 (dd, 8H, aromatic), 3.82-4.10 (s, 6H, 20CH 3$), 3.50-$ $3.57\left(\mathrm{~s}, 1 \mathrm{H}, \mathrm{H}_{4}\right) .{ }^{13} \mathrm{CNMR}$ (DMSO $\left.\delta \mathrm{ppm}\right)$ : $167.50 \quad\left(\mathrm{C}=\mathrm{O}_{\text {lac. }}\right), \quad 163.32 \quad\left(\mathrm{C}=\mathrm{O}_{\text {est }}\right), \quad 131.86$ (C-4), 131.83 (C-3), 131.81 (C-2), (123.44, $114.31,114.28,114.26)\left(\mathrm{C}_{\text {ar. }}\right), 55.90\left(\mathrm{OCH}_{3}\right)$ [14]. The signal of aldehydic carbonyl was disappeared due to it showed out of the scale [16]. MS, (positive ion) $\mathrm{m} / \mathrm{z}$ (relative intensity): $413[\mathrm{M}+1,(100)], \mathrm{UV}\left(\lambda_{\max }, \mathrm{nm}\right.$, $\left.\mathrm{CHCl}_{3}\right): 300$.

\section{Synthesis of Schiff bases (VI-X)}

A mixture of primary aromatic amine $(0.12 \mathrm{mmol})$, aldehyde (V) $(0.05 \mathrm{~g}, 0.12 \mathrm{mmol})$, dry benzene $(10 \mathrm{ml})$ and 2 drops of glacial acetic acid were refluxed for (14) hours, the TLC showed that the reaction was complete (benzene: methanol, 8:2). The solvent was evaporated under vacuum and the residue recrystallized from ethanol. The physical data of all Schiff bases are listed in Table (1). The FTIR spectra data are given in Table (2). ${ }^{1} \mathrm{HNMR}$ (DMSO $\delta \mathrm{ppm}$ ) for compound (VII): $10.16(\mathrm{~s}, 1 \mathrm{H}, \mathrm{HC}=\mathrm{N}),. 7.00-7.90(\mathrm{dd}, 12 \mathrm{H}$, aromatic), $3.82\left(\mathrm{~s}, 6 \mathrm{H}, 2 \mathrm{OCH}_{3}\right), 3.45-3.57$ $\left(\mathrm{s}, 1 \mathrm{H}, \mathrm{H}_{4}\right)[14] .{ }^{1} \mathrm{HNMR}\left(\mathrm{CDCl}_{3} \delta \mathrm{ppm}\right)$ for compound (VIII): 7.78-8.10 (dd, $8 \mathrm{H}$, aromatic.), $7.45(\mathrm{~s}, 1 \mathrm{H}, \mathrm{HC}=\mathrm{N}), 6.27-7.24$ (m, $4 \mathrm{H}$, aromatic), 3.78-3.89 $\left(\mathrm{s}, 9 \mathrm{H}, 3 \mathrm{OCH}_{3}\right)$, 3.61-3.64 (s, 1H, $\mathrm{H}_{4}$ ) [14]. 
Table (1)

Physical properties of compounds (VI-X).

\begin{tabular}{|c|c||c||c||c||c||c||}
\hline $\begin{array}{c}\text { Comp. } \\
\text { No. }\end{array}$ & Nomenclature & $\begin{array}{c}\text { Molecular } \\
\text { Formula }\end{array}$ & $\begin{array}{c}\text { M.p }{ }^{\circ} \text { Cor } \\
\text { dec. }\end{array}$ & $\boldsymbol{R}_{f}$ & $\begin{array}{c}\text { Physical } \\
\text { state }\end{array}$ & $\begin{array}{c}\text { Yield } \\
\%\end{array}$ \\
\hline \hline VI & $\begin{array}{c}\text { (3-Hydroxyphenyl)-imine-pentulose- } \\
\gamma \text {-lactone-2,3-enedianisoate }\end{array}$ & $\mathrm{C}_{27} \mathrm{H}_{21} \mathrm{O}_{9} \mathrm{~N}$ & $110-112$ & 0.54 & Brown solid & 67 \\
\hline VII & $\begin{array}{c}\text { (4-Iodophenyl)-imine-pentulose- } \gamma- \\
\text { lactone-2,3-enedianisoate }\end{array}$ & $\mathrm{C}_{27} \mathrm{H}_{20} \mathrm{O}_{8} \mathrm{NI}$ & $105(\mathrm{dec})$ & 0.68 & $\begin{array}{c}\text { Deep-brown } \\
\text { solid }\end{array}$ & 70 \\
\hline \hline VIII & $\begin{array}{c}\text { (3-Methoxyphenyl)-imine-pentulose- } \\
\gamma \text {-lactone-2,3-enedianisoate }\end{array}$ & $\mathrm{C}_{28} \mathrm{H}_{23} \mathrm{O}_{9} \mathrm{~N}$ & $124-126$ & 0.73 & $\begin{array}{c}\text { Deep-brown } \\
\text { solid }\end{array}$ & 78 \\
\hline \hline IX & $\begin{array}{c}\text { 4-Methylphenyl)-imine-pentulose- } \gamma- \\
\text { lactone-2,3-enedianisoate }\end{array}$ & $\mathrm{C}_{28} \mathrm{H}_{23} \mathrm{O}_{8} \mathrm{~N}$ & $125-127$ & 0.55 & Brown solid & 75 \\
\hline \hline $\mathbf{X}$ & $\begin{array}{c}\text { (4-Nitrophenyl)-imine-pentulose- } \gamma- \\
\text { lactone-2,3-enedianisoate }\end{array}$ & $\mathrm{C}_{27} \mathrm{H}_{20} \mathrm{O}_{10} \mathrm{~N}_{2}$ & $130-133$ & 0.58 & $\begin{array}{c}\text { Light-brown } \\
\text { solid }\end{array}$ & 34 \\
\hline \hline
\end{tabular}

Table (2)

Characteristic FTIR absorption band of compounds (VI-X).

\begin{tabular}{|c|c|c|c|c|c|c|c|}
\hline $\begin{array}{c}\text { Comp. } \\
\text { No. }\end{array}$ & $v(O-H)$ & $v(C-H)_{a r}$ & $v(C-H)_{a l i .}$ & $v(C=O)_{l a c .}$ & $v(C=0)_{\text {est. }}$ & $v(C=N)$ & $v(C=C)_{a r}$ \\
\hline VI & 3304 & 3028 & $\begin{array}{l}2956 \\
2845\end{array}$ & 1770 & 1685 & 1640 & 1602 \\
\hline VII & - & 3028 & $\begin{array}{l}2983 \\
2843\end{array}$ & 1737 & 1685 & 1650 & 1604 \\
\hline VIII & - & 3040 & $\begin{array}{l}2924 \\
2860\end{array}$ & 1760 & 1690 & 1630 & 1604 \\
\hline IX & - & 3028 & $\begin{array}{l}2983 \\
2872\end{array}$ & 1760 & 1685 & 1650 & 1604 \\
\hline $\mathbf{X}$ & - & 3028 & $\begin{array}{l}2983 \\
2843\end{array}$ & 1770 & 1685 & 1629 & 1604 \\
\hline
\end{tabular}

\section{Antibacterial testing}

The bacterial cultures for Staphylococcus aureus, Escherichia coli, Pseudomonas aeruginosa, Streptococcus and Sallemonela were obtained from Center for Market Research \& Consumer Protection Laboratory. The bacterial cultures were incubated at $30 \pm 0.1^{\circ} \mathrm{C}$ for 24 hours by inoculation into nutrient agar. Schiff bases were stored dry at room temperature and dissolved in dimethylsulfoxide (DMSO). Antibacterial activities of each compound were evaluated by the agar disc-diffusion method [17]. Mueller Hinton Agar Media kept at $45^{\circ} \mathrm{C}$ was poured in the Petri dishes and allowed to solidify. Disc injected with prepared Schiff bases $(50 \mu \mathrm{l})$ were applied on the solid agar medium by pressing tightly. The Petri plates were placed at $37^{\circ} \mathrm{C}$ for 24 hours. At the end of period the inhibition zones formed on media were measured with a zone reader in millimeters.

\section{Results and Discussion}

In the present work the synthesis of new Schiff bases were achieved from pentulosono$\gamma$-lactone-2,3-enedianisoate (V), scheme (1). The first step employs the protection of the hydroxyl groups at C-5 and C-6 positions in Lascorbic acid with acetal formation leading to compound (II) using dry acetone in acidic media, following Salomon[13] method. This is followed by esterification of the hydroxyl groups at C-2 and C-3 positions with excess of anisoyl chloride in dry pyridine.

The FTIR spectra for compound (II), Fig.(1) and (III) were confirmed the formation of compound (III) by disappearance of the bands for $(\mathrm{O}-\mathrm{H})$ of compound (II) and 
exhibited the band at $(1683) \mathrm{cm}^{-1}$ for $(\mathrm{C}=\mathrm{O})$ of the ester in compound (III) spectrum.

In order to prepare aldehyde (V), the acetal moiety was cleaved under acidic condition[18] (65\% acetic acid) for compound (III) to give (IV) and oxidation of the product with sodium periodate to result $(\mathrm{V})$, which gave a positive Tolen's test by formation a silver mirror[19]. The FTIR spectra for compound (IV) and (V) were confirmed the formation of compound (V) by disappearance of the bands for $(\mathrm{O}-\mathrm{H})$ of compound (IV) and exhibited the band at (1749) $\mathrm{cm}^{-1}$ for $(\mathrm{C}=\mathrm{O})$ in compound $(\mathrm{V})$ spectrum. The structure of $(\mathrm{V})$ was confirmed by ${ }^{1} \mathrm{HNMR}$, which exhibited a signal at $\delta(12.5) \mathrm{ppm}$ for $(\mathrm{CHO})$ and was characterized by ${ }^{13} \mathrm{CNMR}$, Fig. (2) and (U.V-Vis) spectrum which showed one peak at (300) $\mathrm{nm}$ $\left(33333 \mathrm{~cm}^{-1}\right)$ assigned to $\left(\mathrm{n} \longrightarrow \pi^{*}\right)$ and $\left(\pi \longrightarrow \pi^{*}\right)$ transitions. Finally, the mass spectrum showed a highest mass signal at $[\mathrm{M}+1]=413$ with signal intensity $100 \%$.
In order to obtain compounds (VI-X) by condensation of primary aromatic amines such as (3-amino phenol, (4-iodo, 3-methoxy, 4-methyl, 4-nitro) aniline with aldehyde (V) using dry benzene in acidic media leading to these compounds. All FTIR spectra for these compounds exhibited disappearance of the band at $(1749) \mathrm{cm}^{-1}$ for $(\mathrm{C}=\mathrm{O})$ of the aldehyde (V) and displayed of the bands at (16291650) $\mathrm{cm}^{-1}$ due to $(\mathrm{C}=\mathrm{N})$ for compounds (VI-X), Figs. (3) and (4) FTIR spectra for compounds (VII) and (X). The structures of compounds (VII) and (VIII) were confirmed by ${ }^{1} \mathrm{HNMR}$ which showed disappearance of the signal at $\delta(12.5) \mathrm{ppm}$ for $(\mathrm{CHO})$ and exhibited the signals at $\delta(10.16) \mathrm{ppm}$ and $\delta(7.45) \mathrm{ppm}$ for $(\mathrm{HC}=\mathrm{N})$ in compounds (VII) and (VIII) spectra, Fig. (5) ${ }^{1}$ HNMR spectrum for compound (VII).

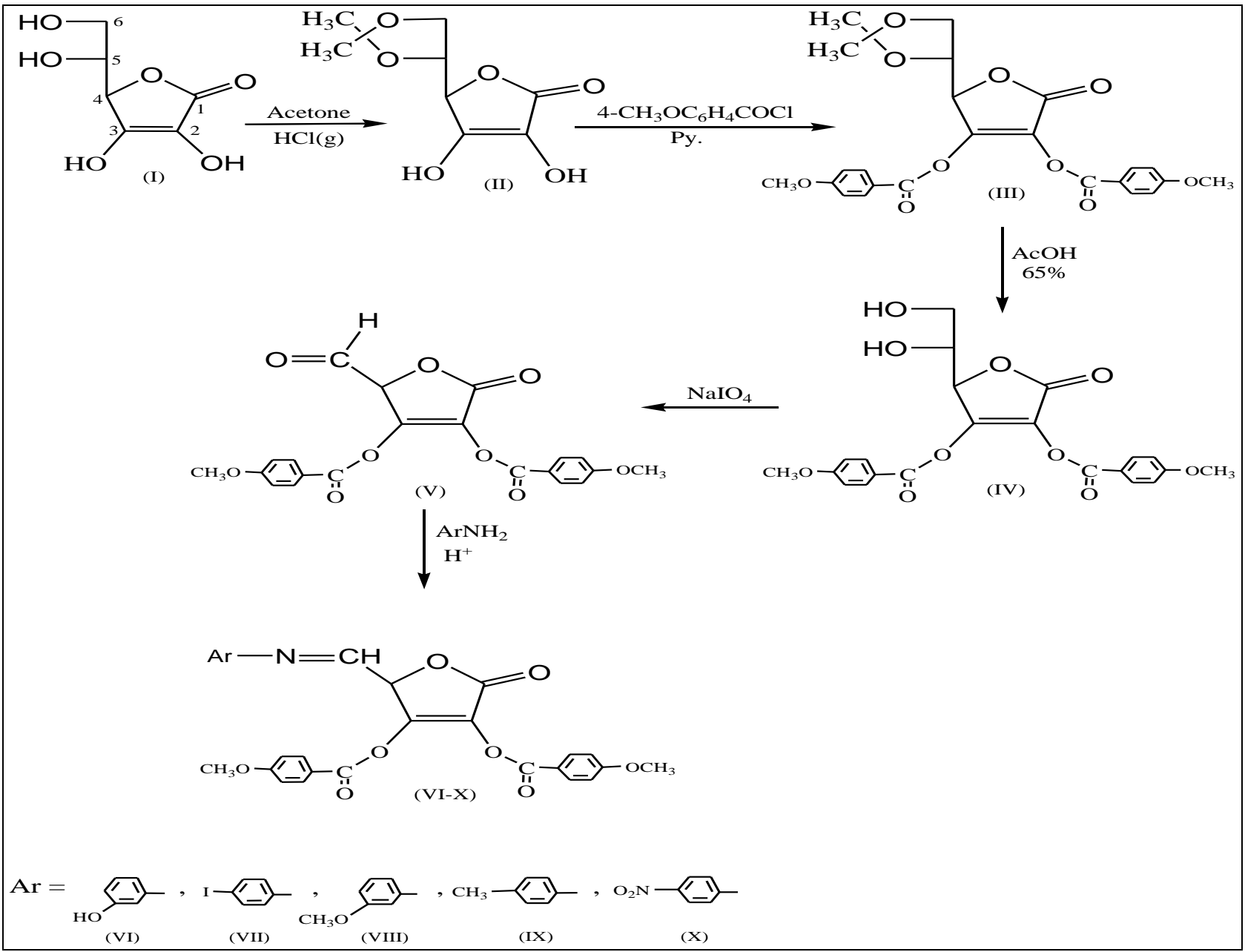

Scheme (1) The scheme of prepared compounds. 


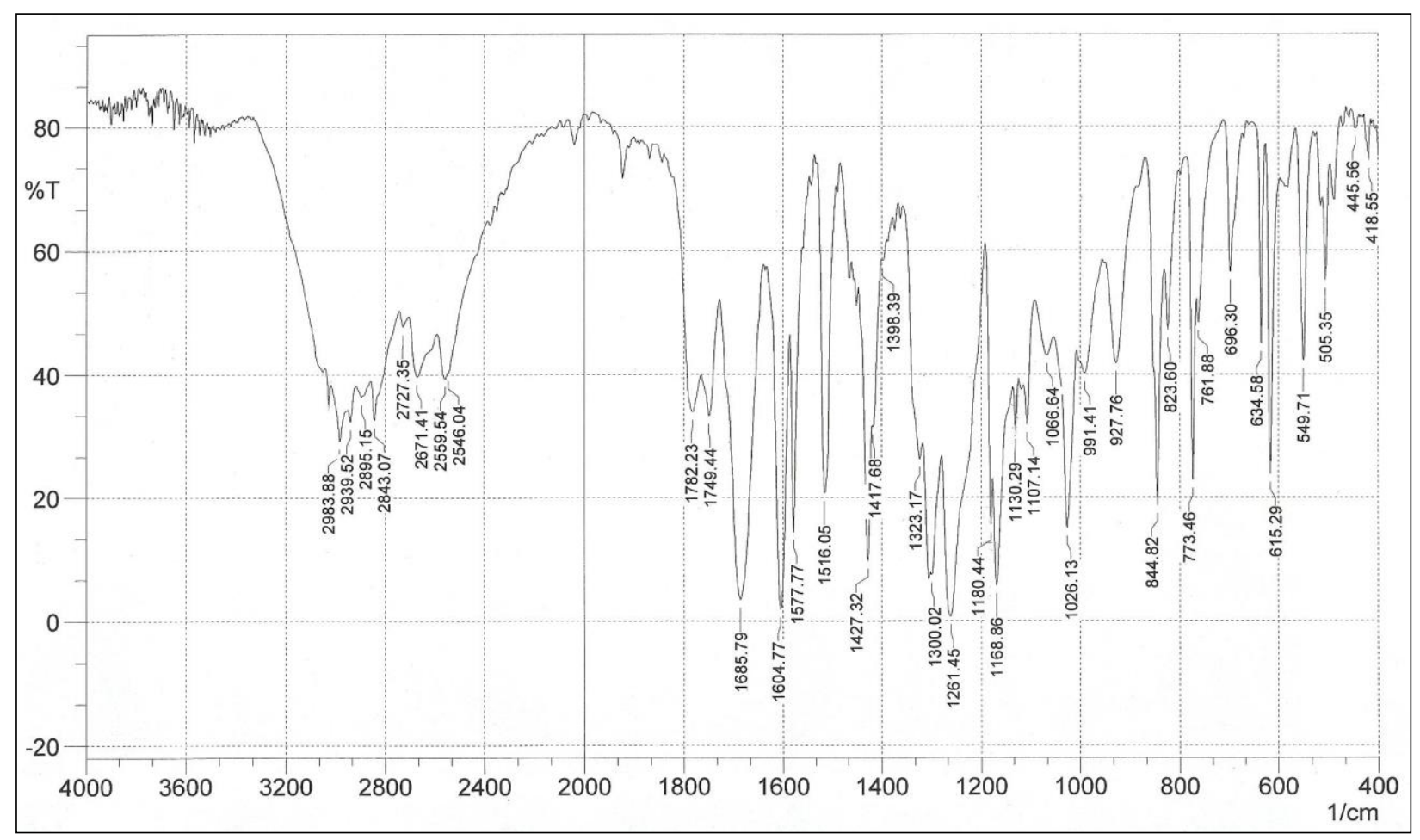

Fig. (1) FTIR- spectrum of compound (V).

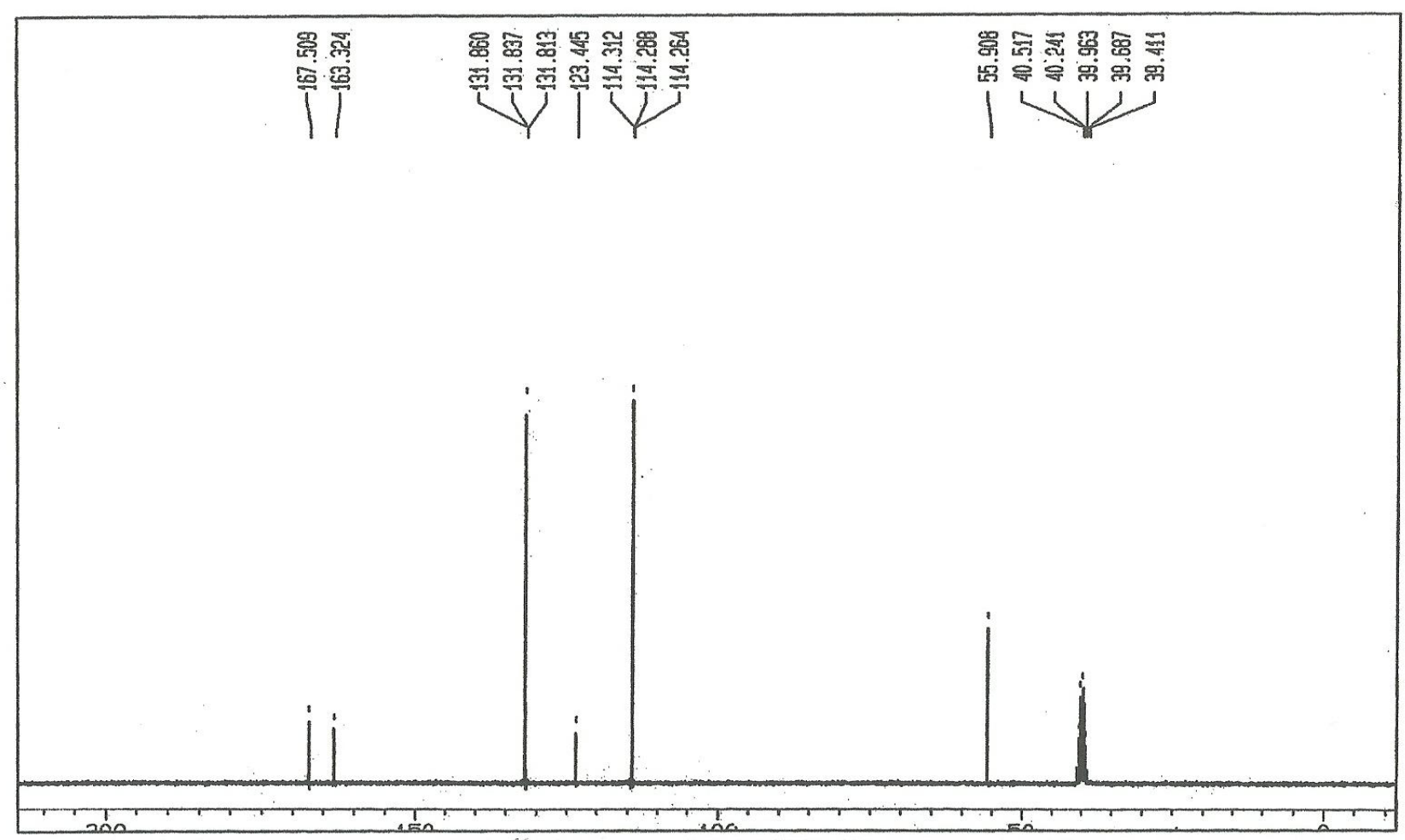

Fig. (2) ${ }^{13}$ CNMR spectrum of compound (V). 
Rasmia M. Rumez

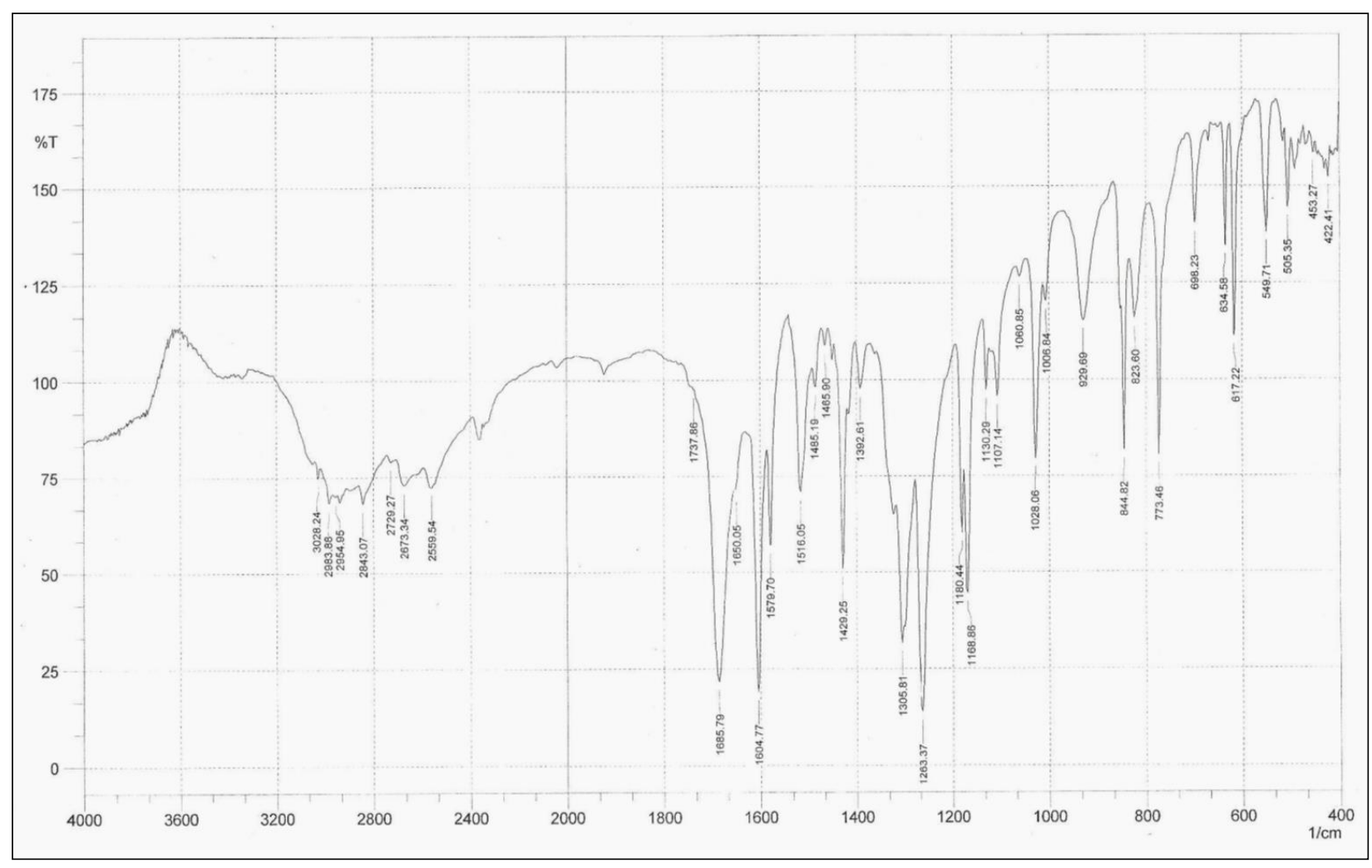

Fig. (3) FTIR- spectrum of compound (VII).

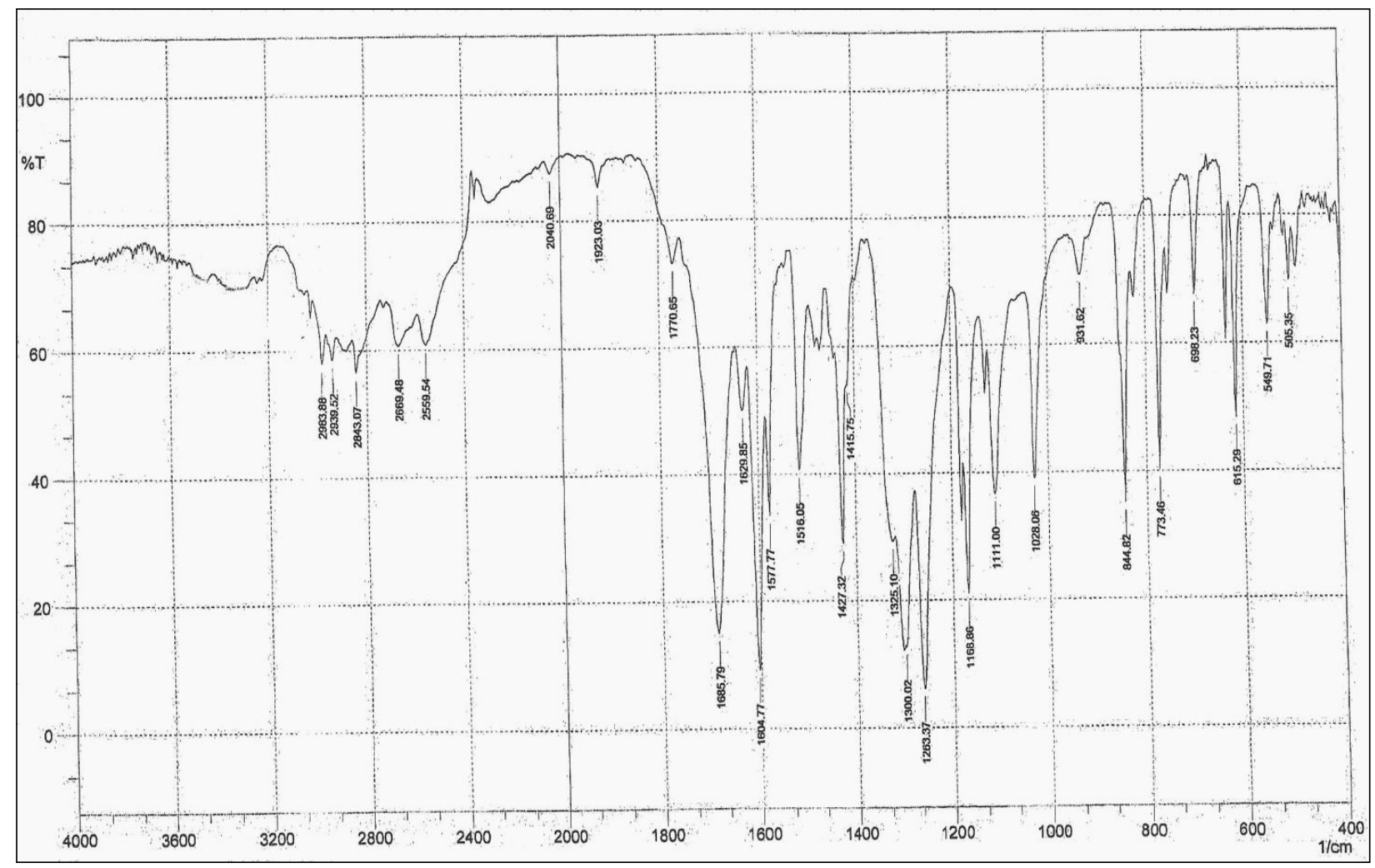

Fig. (4) FTIR- spectrum of compound (X). 


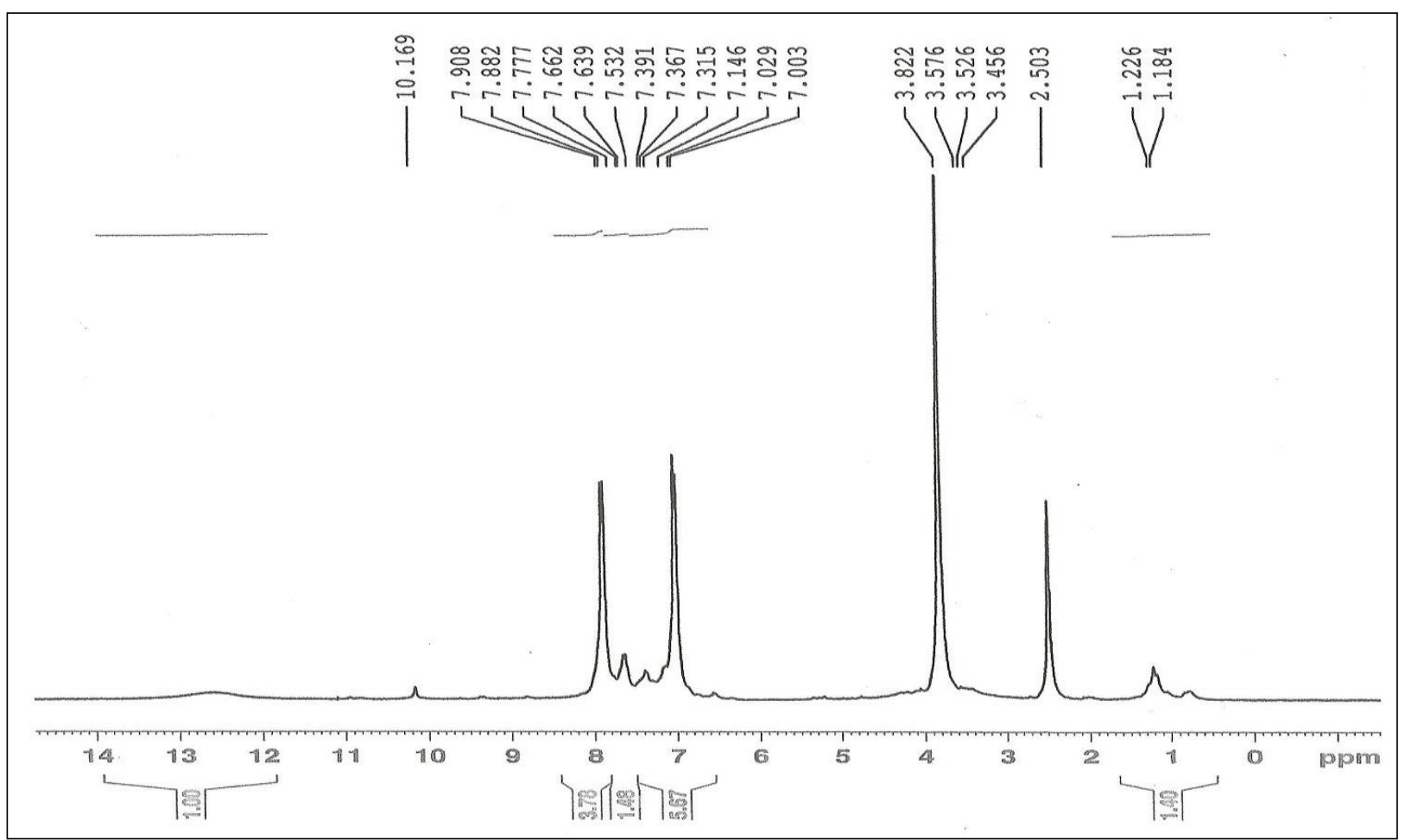

Fig. (5) ${ }^{1}$ HNMR spectrum of compound (VII).

\section{Biological study}

The results of the antibacterial screening of the Schiff bases at a concentration of $20 \mathrm{mg} / \mathrm{ml}$ against all bacteria have been found. The inhibition zones were measured in $\mathrm{mm}$ and results are shown in Table (3). The results of antibacterial screening, indicate that Schiff bases show significant activity against
Staphylococcus aureus, Escherichia coli, Pseudomonas aeruginosa, Streptococcus and Sallemonela while compounds VI, VII, and X were found to be more active against all tested bacterial strains because of the presence of hydroxyl group in the compound (VI) which itself is active against microbes.

Table (3)

Antibacterial activity of compounds (V) and (VI-X).

\begin{tabular}{|c||c||c||c||c|c||}
\hline Comp. No. & S. aureus & E. coli & P. aeruginosa & Streptococcus & Sallemonela \\
\hline \hline V & - & - & - & - & - \\
\hline \hline VI & + & ++ & + & + & + \\
\hline \hline VII & + & + & + & + & + \\
\hline VIII & - & - & - & - & - \\
\hline \hline IX & - & + & - & - & - \\
\hline \hline X & + & + & + & + & + \\
\hline
\end{tabular}

- : $0 \mathrm{~mm},+: 5 \mathrm{~mm},++: 10 \mathrm{~mm}$

\section{Conclusion}

Schiff bases derived from Derythroascorbic acid were successfully synthesized from reaction of aldehyde (pentulosono- $\gamma$ - lactone- 2,3- enedianisoate) with different amines. Schiff bases (VI, VII and $\mathrm{X}$ ) exhibited activity against Staphylococcus aureus, Escherichia coli, Pseudomonas aeruginosa, Streptococcus and Sallemonela while compounds (V, VIII and 
IX) have no effect on these bacteria except compound (IX) showed activity against Escherichia coli.

\section{References}

[1] Popp, F. D. "Synthesis of Potential Anticancer Agents. II. Some Schiff Bases"; J. Org. Chem. 26, 1566-1568, 1961.

[2] Kong, D.; Zhang, X.; Zhu, Q.; Xie, J. ; Zhou, X. Zhongguo Yaown Huaxue Zazhi, 8(4), 245, 1998.

[3] Hadjipavlou-litina, D. J.; Geronikaki, A. A. "Thiazolyl and Benzothiazolyl Schiff Bases as Novel Lipoxygenase's Inhibitors and Anti-Inflammatory Agents, Synthesis and Biological Evaluation"; Drug Des. Discov. 15(3), 199-206, 1996.

[4] Murthy, S. S.; Kaur, A.; Sreenivasalu, B.; Sarma, R. N.; Indian J. Exp. Biol. 36, 724, 1998.

[5] Venugopala, K. N.; Jayashree, V. A. "Microwave-Induced Synthesis of Schiff Bases of Aminothiazolyl Bro-mocoumarins as Antibacterials"; Indian J. Pharm. Sci. 70, 88-90, 2008.

[6] Solak, N.; Rollas, S. "Synthesis and Antituberculosis Activity of 2-(Aryl/ alkylamino) -5- (4-aminophenyl) -1,3,4thiadiazoles and Their Schiff Bases"; Arkivoc 12, 173-181, 2006.

[7] Wadher, S. J.; Puranik, M. P.; Karande, N. A.; Yeole, P. G. "Synthesis and Biological Evaluation of Schiff Base of Dapsone and Their derivative as Antimicrobial Agents"; Int. J. Pharm. Tech. Res. 1(1), 22-33, 2009.

[8] Cates, A. L.; Rasheed, S. M. "Phosphorus GABA Analogues as Potential Prodrugs", Pharm. Res. 1(6), 271-273, 1984.

[9] Kuznetsov, V. V.; Palma, A. R.; Aliev, A. E.; Varlamov, A. V.; Prostakov, N. S. "Regioselective Cyclization of 1-Allyl-1$\alpha(\beta)$-naphthylaminocyclohexanes to 4Methyl- 1, 2, 3, 4- tetrahydrospiro (cyclohexane -1,2- benzo (h(f)) quinolines)"; Zh. Org. Khim. 127, 1579-1581, 1991.

[10] Taggi, A. E.; Hafez, A. M.; Wack, H.; Young, B.; Ferraris, D.; Lectka, T. "The Development of the First Catalyzed Reaction of Ketenes and Imines: Catalytic, Asymmetric Synthesis of b-Lactams"; J. Am. Chem. Soc. 124, 6626-6635, 2002.
[11] (a) Tsuge, O.; Kanemasa, R. "Recent Advances in Azo-methine Ylide Chemistry", Adv. Heterocycl. Chem. 45, 231-349, 1989. (b) Aly, M. F.; Younes, M. I.; Metwally, S. A. M. "Non- Decarboxylative 1,3-Dipolar Cycloadditions of Imines of $\alpha$-Amino Acids as a Route to Proline Derivatives"; Tetrahedron 50(10), 3159-3168, 1994.

[12] Patil, S.; Jadhav, S. D.; Patil, U. P. "Natural Acid Catalyzed Synthesis of Schiff Base under Solvent-free Condition: As a Green Approach"; Archives of Applied Science Research 4 (2), 1074-1078, 2012.

[13] Salomon, L. L. "Preparation of 5,6-OIsopropylidene-L- Ascorbic Acid"; Experientia 19(12), 619-620, 1963.

[14] Dudley, H.; Fleming, I. "Spectroscopic Methods in Organic Chemistry", $5^{\text {th }}$ Ed., McGraw-Hill companies, London; Vol. 24; 1995.

[15] Al-Rawi, M. S.; Ph. D. Thesis "Synthesis of New Heterocyclic Derivatives of DErythroascorbic acid"; Baghdad University, 2011.

[16] Carey, F. A. "Organic Chemistry"; $6^{\text {th }}$ Ed., the McGraw-Hill Companies, Inc., New York; pp. 767; 2006.

[17] Ugras, H. I., Cakir, U., Azizoglu, A., Kilic, T., and Erk, C. "Experimental, Theoretical and Biological Activity Study on the Acyl-Substituted Benzo-18-crownDibenzo-18-crown-6 and Dibenzo-24crown-8"; Journal Indusion Phenomena and Macrocyclic Chemistry 55, 159-165, 2006.

[18] Gazivoda, T.; Wittine, K.; Lovric, I.; Makuc, D.; Plavec, J.; Cetina, M.; MrvosSermek, D.; Suman, L.; Kralj, M.; Pavelic, K.; Mintas, M.; Raic-Malic, S. "Synthesis, Structural Studies, and Cytostatic Evaluation of 5,6-Di-O-modified LAscorbic Acid Derivatives"; Carbohydr. Res. 341 (4), 433-442, 2006.

[19] Vogel, A. I. "Vogel's Textbook of Practical Organic Chemistry"; $5^{\text {th }}$ Ed., John Wiley and Sons, Inc., New York; pp. 1219; 1989. 


\section{الخلاصة}

تم تحضير عدد من قواعد شف الجديدة المشتقة من

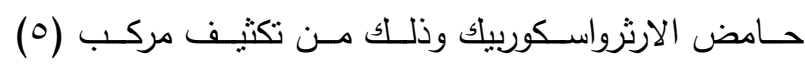

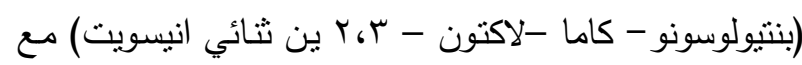

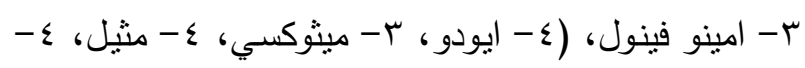

نايترو) انيلين بوجود حامض الخليك التلجي والبنزين الجاف.

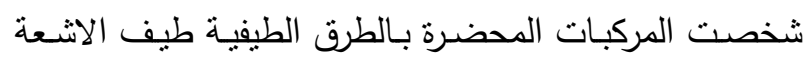

تحت الحمراء، وبعضها بواسطة طيف الاثعة فوق البنفسجية

والمرئيـة، طيف الرنين النووي المغناطيسي, طيف الكنلة و ولئه

قياس بعض خصائصها الفيزيائية وتقييم الفعالية الحيوية لها.

الكلمات المفتاحية: قواعد شف، ايمين، الفعالية الحيوية،

حامض الارثرواسكوربيك. 